症例

急性腹症にて緊急手術を要した後腹膜原発 malignant mixed Müllerian tumor $の 1$ 例

\author{
京都第二赤十字病院外科 \\ 上原正弘泉浩竹中温
}

症例は60歳，女性、腹痛で来院し，卵巣腫煌出血の疑いで緊急手術を行った，開腹所

見は，後腹膜から S 状結腸へ浸潤した血腫を伴う腫湯を S 状結腸と共に切除し，術中病 理診断で germ cell origin 様との事で, 子宮と両側附属器切除も加えた. 術後性器外 malignant mixed Müllerian tumor (MMMT) と診断され，AP 療法施行したが，腹 腔内再発を認め, 現在 paclitaxel, carboplatin の併用にて加療している. MMMT は, 悪性の上皮と間葉成分の混在する子宮腫場として1854年に最初に報告され, Müller 管の biphasic な分化能を具現し, Müller 管中肧葉起源説が定説とされる. 性器外 MMMT の 報告は，1955年 Ober WB と Black MB の最初の報告以来，自験例を含め31例存在し， 治療は手術療法の他に，様々な化学療法が施行され，予後不良である。

索引用語：後腹膜原発, malignant mixed Müllerian tumor

はじめに

malignant mixed Müllerian tumor (MMMT) は, 覀性の上皮成分と間葉成分の混在する子宮腫煬として 1854年に最初に報告され，Müller 管の biphasic な分 化能を具現する腫場とされ, その組織発生は Müller 管中胚葉起源説が定説とされている⿱12). 性器外 NIMINT の報告は, 1955年に Ober WB と Black MB ${ }^{31}$ が最初に報告して以来, 自験例を含め31例の報告があ るのみである(1) . 今回われわれは, 急性腹症のため緊 急手術を要し現在も術後化学療法にて経過観察中であ る性器外 MMMTの1例を経験したので文献的考察 を加え報告する。

\section{症例}

患者：60歳, 女性（初潮：15歳, 閉経：51歳・自然 閉経, 2 妊 2 産)。

既往歴：20歳，虫垂炎にて虫垂切除術51藏より高血 圧, 高脂血症にて pravastatin sodium, alacepril, trichlormenthiazide 内服中（ホルモン刘内服歴なし）.

職業：現在無職, 過去に印刷工場, 織物工場に勤務。 家族歴：母：高血圧，兄；直腸癌。

2001 年 9 月 25 日受付 2001 年12月 10 日採用

〈所属施設住所〉

テ602-8026 京都市上京区釜座通丸太町上ル春帯町355- 5
現病歴：2000年11月頃より左下腹部痛を自賞し, 当 院消化器科受䛦し, 腹部超音波検査, 便検査施行する も異常所見指摘されず, 2001年 2 月11日に下腹部痛出 現し, 近医受診するも異常なしとされたが不正性器出 血を伴っていた為, 当院外来受診し入院精查施行した.

入院時検查所見：血液生化学検査は, CRP が7.07 $\mathrm{mg} / \mathrm{dl}$ と高値を示し, グロブリンが $3.7 \mathrm{~g} / \mathrm{dl}$ と高值を 示す以外岎血等の所見はなく, 腫偒マーカーは $\alpha-7$ エトプロテインのみ $122 \mathrm{ng} / \mathrm{ml}$ と高值を示した(表 1$).$

画像所見：腹部X線において異常所見はなかった。 腹部単純 CT では骨盤内に内部に液状成分を含んだ約 $8 \times 5 \mathrm{~cm}$ の heterogenic mass が存在した. 腫崵辺縁 は比較的明膫で腹水は著明には存在しなかった（図 1 a)。また，右上腹部の上行結腸腹側に約 $4 \times 3 \mathrm{~cm}$ の 一部 low dencity area を含む腫瘤が存在し, 腹壁との 境界は一部不明瞭であった(図 1 b) 。経膣超音波所見 では, $9.1 \times 7.7 \mathrm{~cm} の$ heterogenic mass が存在し, 周 囲に腹水も存在していた（图 2 ).

以上より，疼痛コントロール不良抢よび左卵巣腫瘍 出血, 大網転移を疑い, 開腹術を施行した。

手術所見：腫瑒が後腹膜より $\mathrm{S}$ 状結腸に浸潤し，そ の間に血腫が存在し, 腫瘍は約 $8 \mathrm{~cm}$ の表面不整, 弾性 軟なものであった (図 3 ). 腹腔洗净細胞診は, class 5 であった。 
表 1 入院時検査所見

\begin{tabular}{|c|c|c|c|}
\hline 紷蛋白量 & $7.3 \mathrm{~g} / \mathrm{dl}$ & 白血球 & $7,700 / \mathrm{mm}^{3}$ \\
\hline アルブミン & $3.54 \mathrm{~g} / \mathrm{dl}$ & 赤血球 & $366 \times 10^{4} / \mathrm{mm}^{3}$ \\
\hline グロブリン & $3.76 \mathrm{~g} / \mathrm{dl} \uparrow$ & 血色素量 & $11,5 \mathrm{~g} / \mathrm{dl}$ \\
\hline 総ビリルビン & $0.9 \mathrm{mg} / \mathrm{dl}$ & ヘマトクリット & $31.0 \%$ \\
\hline ALP & $72 \mathrm{IU} / \mathrm{L}$ & 血小板 & $26.9 \times 10^{4} / \mathrm{mm}^{3}$ \\
\hline GOT & $11 \mathrm{IU} / \mathrm{L}$ & & \\
\hline GPT & $16 \mathrm{IU} / \mathrm{L}$ & CA19-9 & $4 \mathrm{U} / \mathrm{ml}$ \\
\hline LDH & $419 \mathrm{IU} / \mathrm{L}$ & $\mathrm{CA} 125$ & $24 \mathrm{U} / \mathrm{ml}$ \\
\hline BUN & $7.6 \mathrm{mg} / \mathrm{dl}$ & $\alpha>$ フェトプロテイン & $122 \mathrm{ng} / \mathrm{ml}$ v \\
\hline クレアチニン & $0.7 \mathrm{mg} / \mathrm{dl}$ & CEA & $0.7 \mathrm{ng} / \mathrm{ml}$ \\
\hline 血糖 & $121 \mathrm{mg} / \mathrm{dl}$ & & \\
\hline 総コレステロール & $161 \mathrm{mg} / \mathrm{dl}$ & & \\
\hline CRP & $7.07 \mathrm{mg} / \mathrm{dl} \hat{\imath}$ & & \\
\hline
\end{tabular}

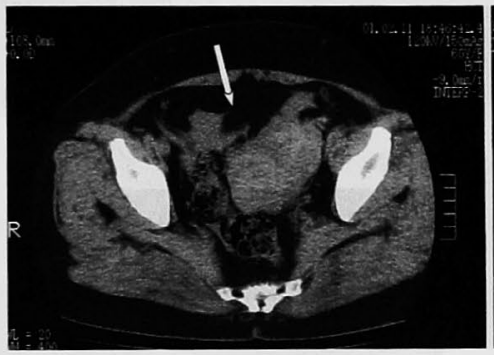

a



b

図 1 腹部単純 CT 所見：a )骨盤内に内部に液体成分を含んだ, 辺緑比較的明瞭 な heterogenic mass が存在した。 b ) 右上腹部の上腹部腹側に一部 low dencity area を含む腫瘤が存在した。

さらに腹腔内を検索するに，大網に同じ性状の大小 結節が多発性に存在した。

なお，子宮をはじめ両側附属器には肉眼的に異常を 認めなかった。

$\mathrm{S}$ 状結腸の腸間膜側に一部腫瘍の癒着が見られた 為, 腫瘍と共にS 状結腸切除術を施行し, 術中病理診 断を施行した。その結果，腫湯組織は大型の極性を失 った核を有し,崩れた管状構造または slit 状, 索状構造 を有する腫湯で，間質は germ cell origin 様々である との事であった為, 子宮および附属器原発腫瘍の転移 も疑い, 子宮全摘術および両側附属器切除を加え, さ らに，大網切除も加えた.

病理検査結果：肉眼的に腸間膜に出血を伴う腫瘍性 変化を認め, H-E 染色では, N/C 比の高い異型上皮が 不規則な乳頭状または管状構造を形成し，間質成分は 肉腫様で，部分的に軟骨様の分化や myoblast への分 化を示す成分も存在していた（図 4 a， b). 子宮およ び両側附属器には悪性所見はなかった。
さらに特殊免疫染色の内, EMA, S-100, SMA, vimentin, Ber-EP 4 にて陽性所見が存在した。

以上より, 後腹膜原発 malignant mixed Müllerian tumor (heterologous type) と診断した.

術後治療および経過：術後経過良好につき，化学療 法 (AP 療法) 施行した，その後，2001年 7 月に術後正 常值を示していた $\alpha$-フェトプロテインが50ng/ml と 高値を示し，画像上左総腸骨動脈周囲および左下腹部 腹膜に，それぞれ直径約 $3 \mathrm{~cm}$ の再発と思われる腫瘤 が出現し, paclitaxel, carboplatin の併用療法を開始 し継続治療中である。

\section{考 察}

MMMT は，悪性の上皮成分と間葉成分の混在する 子宮腫湯として Wagner により1854年に最初に報告 され，Müller 管の biphasic な分化能を具現する腫煌 とされ，その組織発生は Müller 管中胚葉起源説が定 説とされている12). 子宮悪性腫瘍の約 $1 \%$ を占めると され(10)，5年生存率も本邦において $10 〜 20 \%$ 開きが 
あるものの予後は不良で, 術後 2年以内に再発死亡す る者が多いとされている゙”. 今回われわれの経験した 性器外 MINIT は, 1955年に Ober WB と Black $\mathrm{NB}^{3 \prime}$ が最初に報告して以米, 自験例を含め31例の報告

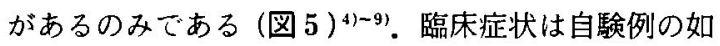
く腹痛, 腹部膨満感などを示すものが多く, 腹部腫瘤 を触知する事もあるとされているが MMMT 独自の 臨床症状はない様である゙!。

自験例を含めた性器外 MMMTは20〜82歳 (mean \pm S. D. =61.3土14.4歳)にみられ，51歳以上が 大多数を占めた。この腫湟の発生の原因は諸説存在し, 内膜症からの発生, 放射線治療の影響と secondary Müllerian system の存在が主に提唱されているが,一 定した見解は得られていないのが現状であるいいッ。 れわれが検索しえた文献および自験例において，子

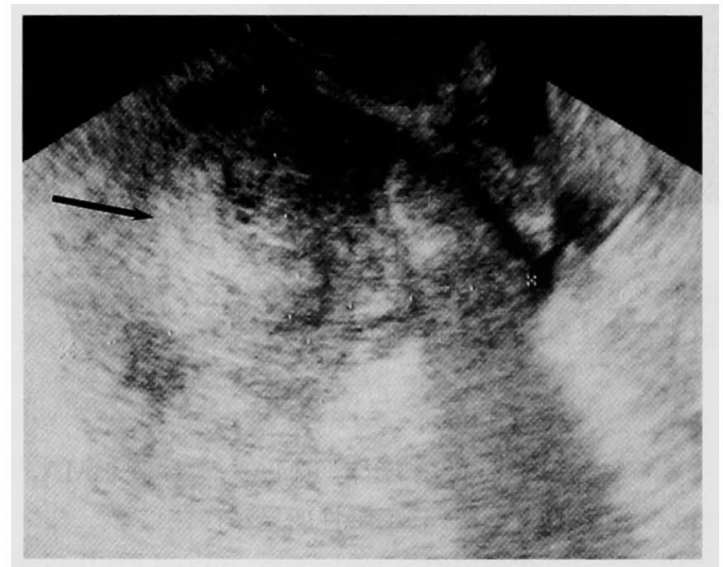

図 2 経胵超音波所見：周囲に腹水を伴う, hetrogenic mass が存在した.
宮·附属器の既往歴があったものは30.0\% ( 9 例) で, 内膜症の存在したものは $6.5 \%$ ( 2 例) であった。 また 放射線治療の既往があったものは $16.1 \%$ (5 例) であ り，この結果からも発生原因として有力とは言えない

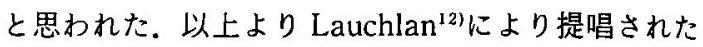
subcoelomic mesenchymeの関与する secondary Müllerian system が, 性器外 MMMT の発生に関与 している可能性がある899.

MMMT は, 病理学的には大きく homologous type と heterologous type にわけられている(7) ${ }^{40)}$. 今回の 検討では homologous type は35.5\% (11例), heterologous type は64.5\% (20例) で生存期間が判明して いる症例の検討で，3 3 月以内に原病死した症例は homologous type ( 8 例中) が $12.5 \%$ ( 1 例) で, heter. ologous type（9例中）が44.5\% (4 例) との結果で あり, heterologous type は予後不良である可能性が示

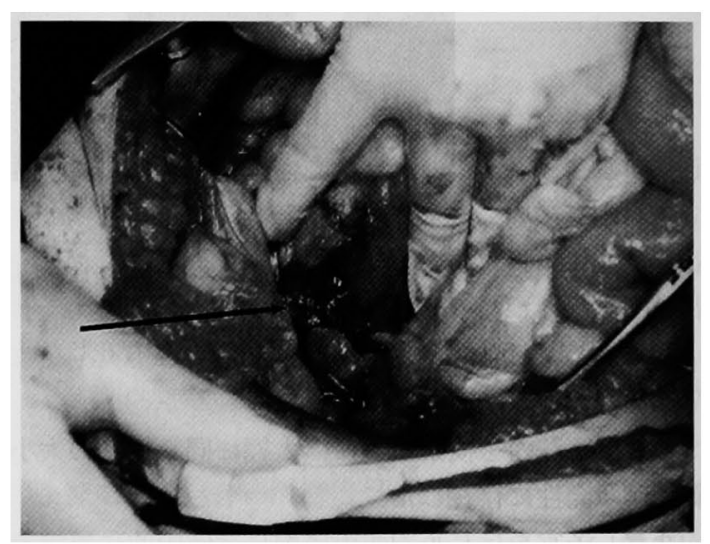

図 3 術中所見：後腹膜より $\mathrm{S}$ 状結腸に浸潤を示し, 血 腫を伴った表面不正な弾性硬の腫瘍が存在した。



a

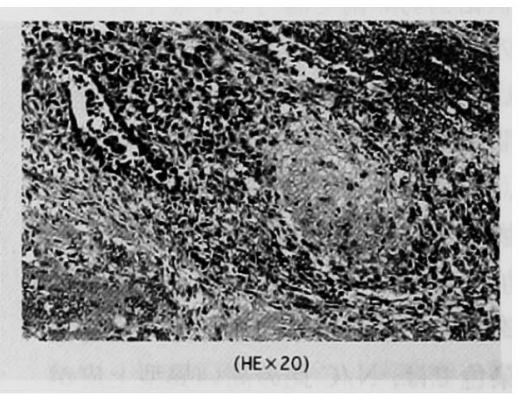

b

図 4 病理検查所見：a） N/C 比の高い異型上皮が不規則な乳頭状または管状構 造を形成し, 間質成分は肉腫様であった。 b ) 部分的に軟骨様の変化や myoblast への分化を示す成分も存在した. 

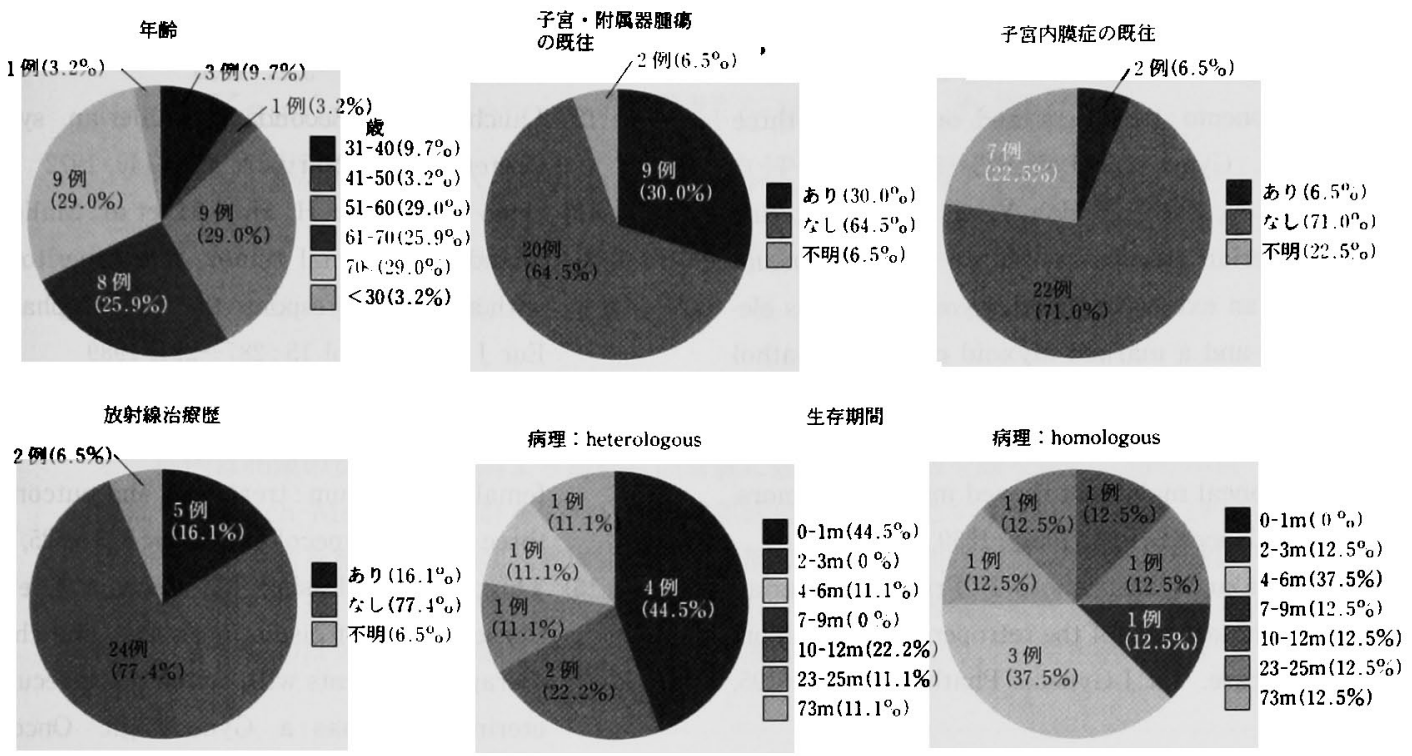

図 5 性器外 MMMT（31例）の検討

唆された。ただしここの鑑別は画像診断では困難であ ク，摘出標本により診断可能である．MMMTは，悪 性の上皮性成分と間葉性成分の混在する腫場というこ とより, 病理学的診断において PAS 染色, PTAH 染 色, Azan 染色において陽性を示し, 免疫組織化学染色 では cytokeratin, EMA, Vimentin, S-100, DesminHHF35，Myo-1において陽性を示したとの報告があ り", 今回われわれの検討では, E.MA, S-100, S.IA, vimentin, Ber-EP 4 にて陽性を示した。

治療に関しては，主に外科手術が施行されている。 術後補助療法に関して, Ohno ら ${ }^{(3)}$ は, 性器外 MMMT の化学療法を受けたものの多くは進行度に関わらず1 年以内に死亡したと報告している。 その一方，手術後 補助療法を施行せず 1 年間の無病期間があった症例も 存在している7!.現在, 様々に組み合わされた化学療法 において，一定した見解が得られていないのが現状で ある゙. 卵巣の MMMTについてではるが, Gynecologic Oncology Group は MMMT の17〜25\% に効果を示したものとして, ifosfamide と cisplatin を示した ${ }^{14) 15)}$. Sit $~^{16)}$ は, 2 種の化学療法用の組合せ で paclitaxel/carboplatin (PC) と platinum/ifosfamide (PI) を比較しているが，それぞれの median survival time は19力月と23力月で, platinumをべー スとした paclitaxel や ifosfamide を組み合わせた化 学療法が効果的ではないかとしている.ただし, 性器 外 MMMTに対する化学療法の効果の検討をした文
献は検索しえず，今後の検討が期待される。

\section{結語}

緊急手術を要した, 極めて稀な性器外 MMMT の 1 例を経験したので文献的考察を加え報告した。

稿を終えるにあたり, 御指導頂いた当院病理科の加藤元 一先生, 永田昭博先生, 産婦人科の荻野嘉夫先生, 福岡正晃 先生に深謝いたします。

文献

1)鈴木浩基, 岩田 睦, 三浦史晴他：乳癌術後に発 見された Malignant Müllerian Mixed Tumor (MMMT) の 1 例. 岩手病医会誌 $39: 54-5 \pi$, 1999

2）林 哲朗, 西村俊満, 今泉利信他：悪性ミュラー 管混合腫瘍の 1 症例. 日臨細胞会九州誌 $2 x: 83$ -86, 1997

3) Ober WB, Black MB: Neoplasm of the subcoelomic mesenchyme: repor of two cases. Arch Phathol Lab Med 59 : 698-705, 1955

4) Garamvoelgyi E, Guillou L, Gebhard S, et al : Primary malignant mixed Müllerian tumor (metaplastic carcinoma) of the female peritoneum. Cancer 74:854-863, 1994

5) Choong SYM. Scurry JP, Planner RS, et al: Extrauterine malignant mixed Müllerian tumor of primary peritoneal origin. Phathology $26: 497-498,1994$ 
6) Rose PG, Rodriguez M, Abdul-Karim FW: Malignant mixed mullerian tumor of female peritoneun : treatment and outcome of three cases. Gynec Oncol 65:523-525, 1997

7) Kato N, Zhe J, Endoh Y, et al: Extrauterine Mullerian adenosarcoma of the peritoneum with an extensive rhabdomyosarcomatous element and a marked myxoid change. Phathol Int $50: 347-351,2000$

8) Shen DH, Khoo US, Xue WC, et al: Primary peritoneal malignant mexed müllerian tumors. Am Cancer Sci 91 : 1052-1060, 2001

9) Shintaku M, Matsumoto T : Primary múllerian carcinosarcoma of the retroperitoneum : report of a case. Int J Gynecol Phathol 20:191-195, 2001

10）関谷隆夫, 吉松和彦, 根本芳広他：33歳で発症し た子宮 Carcinosarcoma $の 1$ 例。日産婦神奈川会 誌 $33: 36-40,1996$

11）村上隆浩, 日浦昌道, 藤岡 徽他：穿刺細胞診が 有用であった術後 7 年目に再発した墨性ミューラ
一管混合腫瘍 (MMMT) の 1 症例，日産婦中国四 国会誌 $44: 318-322 ， 1996$

12) Lauchlan SC:Secondary Müllerian system. Obstet Gynecol Surv 27 : 133-146, 1972

13) Ohno S, Kuwano H, Mori M, et al : Malignant mixed mesodermal tumor of the peritoneum with a complete response to cyclophosphamide. Eur J Surg Oncol 15:287-291, 1989

14) Rose PG, Rodriguez M, Abdul-Karim FW: Malignant mixed Mullerian tumor of the female peritoneum : treatment and outcome of three cases. Gynecol Oncol 65:523-525, 1997

15) Thigpen JT, Blessing JA, Becham J, et al: Phase II trial of cisplatin as first line chemotherapy in patients with advansed or recurrent uterine sarcomas:a Gynecologic Oncology Group study. J Clin Oncol 9: 1962-1966, 1991

16) Sit ASY, Price FV, Kelley JL, et al : Chemotherpy for malignant mixed müllerian tumors of ovary. Gynecol Oncol 79:196-200, 2000

\title{
A CASE OF MALIGNANT MIXED MÜLLERIAN TUMOR OF THE RETROPERITONEUM DEMANDED AN EMERGENCY OPERATION FOR ACUTE ABDOMEN
}

\author{
Masahiro UEHARA, Hiroshi IZUMI and Atsushi TAKENAKA \\ Department of Surgery, Kyoto Daini Red Cross Hospital
}

A 60-year-old woman was seen at the hospital because of abdominal pain and underwent an emergency operation with a suspicion of an ovarian tumor. Upon laparotomy, a tumor infiltrating from the retroperitoneum to sigmoid colon with a hematoma was present, and the tumor with the sigmoid colon was excised. Intraoperative frozen section diagnosis suggested germ cell origin, and so a hyster. ectomy and an excision of bilateral uterine supports were added. After the operation, extragenital malignant mixed Müllerian tumor (MMMT) was diagnosed. Despite AP therapy, intraabdominal recurrence was confirmed. The patient has been treated with paclitaxed and carboplatin combinedly.

MMMT was first reported as a tumor of the uterus composed of malignant epithelium and mesenchyme in 1854. It is the established theory that the tumor embodies a biphasic differentiation of the Müllerian duct and originates in mesoderm of the Müllerian duct. Since the first report of extragenital MMMT by Ober WB and Black MB in 1955, there have been 31 cases including this case. A variety of chemotherapies other than operation have been conducted, but the prognosis of the disease is poor. 